\author{
Katarzyna Krzemińska \\ PWSZ we Wtoctawku
}

\title{
EUROPEJSKIE PORTFOLIO JĘZYKOWE JAKO INSTRU- MENT SAMOOCENY PRAC PISEMNYCH NA POZIOMIE ZAAWANSOWANYM W NAUCE JĘZYKA OBCEGO
}

\section{The European Language Portfolio in self-evaluation of foreign language writing skills at the advanced level}

\begin{abstract}
The purpose of this article is to explore the role of the ELP in teaching language skills to students of foreign languages, in my professional situation - to German Language and Literature students. The article attempts to answer the following questions: To what extent do the ELP and the Council of Europe documents help students of foreign languages use self-evaluation? How do these documents support learner autonomy? Due to the growing interest in the ELP, I focused my attention on the use of self-evaluation skills by college students during their writing tasks. The article presents the results of a study on self-evaluation. It was carried out among first and second year students of German Language and Literature Studies at the State Higher Education College in Włocławek in the academic years 2005/2006 and $2006 / 2007$.
\end{abstract}

\section{Wstęp}

Zarówno Unia Europejska jak i Rada Europy podejmują szereg działań dążących do zmiany celów, metod, środków i treści nauczania języków obcych. Zadaniem europejskiej polityki językowej jest bowiem odpowiedź na pytania, jakich języków nauczać, w jakim celu i w jakim stopniu (Pfeiffer 2001). Aby umożliwić realizację nowych celów wprowadzono zatem do praktyki dydaktycznej konkretne narzędzia takie jak Europejski System Opisu Kształcenia Językowego (ESOKJ), określający zakres 
umiejętności, wiedzy i sprawności wymagany na poszczególnych poziomach biegłości językowej oraz Europejskie portfolio językowe (EPJ), którego zadaniem jest między innymi zharmonizowanie polityki edukacyjnej krajów Unii Europejskiej, rozwijanie tolerancji wobec innych narodowości i kultur, wspieranie mobilności mieszkańców państw członkowskich, ale również na przykład stworzenie porównywalnych kryteriów oceny kwalifikacji językowych. Istotnym zagadnieniem w Europejskim portfolio językowym jest unowocześnione podejście do oceny wyników nauczania.

W dzisiejszym podejściu dydaktyki języków obcych można zaobserwować dążenie, aby nauczanie języka obcego było skierowane na ucznia, uwzględniało jego potrzeby i oczekiwania (Pfeiffer 2001). Proces nauczania języka obcego powinien zatem zachęcać do samodzielnej nauki, za którą uczeń przejmuje w pewnym stopniu odpowiedzialność i uniezależnia się od nauczyciela.

Niezwykle ważną rolę odgrywa w procesie nauczania i uczenia się ocenianie wiedzy i umiejętności. Obiektywna ocena motywuje ucznia i ma walory wychowawcze; może być jednakże odebrana jako subiektywna i niesprawiedliwa, dlatego warto przygotować uczniów do samooceny. W Europejskim Systemie Opisu Kształcenia Językowego podkreśla się dużą wartość samooceny jako sposobu wzmacniania motywacji i świadomości językowej, tzn. wspierania uczących się w wykorzystywaniu własnych atutów i rozpoznawania słabych stron, a przez to sterowania własnym uczeniem się. Zarówno motywacja jak i autonomia uczących się są silnie zaakcentowane w Europejskim portfolio językowym.

O ile często mówi się o rozwijaniu autonomii uczących się w zakresie sprawności mówienia, o tyle trudniej uczynić to w odniesieniu do sprawności pisania, gdyż w praktyce dydaktycznej pisanie było przez długi czas postrzegane jako sprawność wtórna, trudna do opanowania i mało przydatna w codziennej komunikacji (Zuchewicz 2002). Również obecnie zagadnienie rozwijania sprawności pisania na poziomie zaawansowanym rzadko stanowi przedmiot badań. Nie można jednakże zapominać, iż procesy produkcji językowej (zarówno w języku mówionym jak i pisanym) stanowią o kompetencji językowej uczącego się. Można zatem wspierać dane procesy w ramach autoewaluacji, rozwijając autonomię uczących się przy pomocy innowacyjnego instrumentu, jakim jest Europejskie portfolio językowe. Innowacyjne portfolio jest bowiem urzeczywistnieniem idei, która w dydaktyce języków obcych obecna jest już od dawna. Za sprawą portfolio, w praktyce zawodowej nauczycieli nabiera na znaczeniu hasło: uczymy się, jak uczyć (Bimmel/Rampillon 2000). Europejskie portfolio językowe rozwija bowiem między innymi umiejętność oceny własnej kompetencji językowej ucznia, uczy umiejętności refleksji nad procesem uczenia się (w tym przypadku - rozwijaniem sprawności pisania), kształtuje postawy autonomiczne wśród uczących się, ułatwia świadome planowanie uczenia oraz rozwija motywację do uczenia się języków obcych.

Artykuł przedstawia zatem wyniki badań, których głównym zadaniem jest rozwijanie umiejętności samooceny w zakresie sprawności pisania na poziomie zaawansowanym. Autorka szuka także odpowiedzi na pytania, czy i w jakim stopniu Europejskie portfolio językowe wspiera autonomię studentów filologii germańskiej 


\section{Badanie action research}

Celem przeprowadzonych badań jest próba potwierdzenia hipotezy, która brzmi w następujący sposób: Europejskie portfolio językowe jako instrument samooceny pisemnych prac na zaawansowanym poziomie nauki języka obcego może w znacznym stopniu przyczynić się do rozwoju autonomii uczących się i wspierać rozwijanie sprawności pisania. W ramach postawionej hipotezy podjęto próbę odpowiedzi na cztery szczegółowe pytania badawcze, które przedstawiono w dalszej części artykułu.

Badania przeprowadzono w latach 2005/06 oraz 2006/2007 w Instytucie Neofilologii na kierunku filologii germańskiej w Państwowej Wyższej Szkole Zawodowej we Włocławku. Za podstawę prowadzenia badań przyjęto metodologię badań w działaniu (ang. action research) ${ }^{5}$. Badania zostały przeprowadzone w niewielkich grupach studenckich filologii germańskiej a postawione pytania problemowe były rozwiazywwane w ramach tej populacji. Badania prowadziłam osobiście w ramach zajęć z praktycznej nauki języka niemieckiego (PNJN) pod nazwa - redagowanie tekstów. Badani prowadzili w ramach Europejskiego portfolio językowego teczki, w których zbierali swoje prace, oceniali je i opisywali. W ramach badań analizowano trzy rodzaje tekstów: list prywatny, streszczenie i sprawozdanie. Jako narzędzia badawcze wykorzystałam ankiety, wywiady, dzienniczki i zapiski studentów. W badaniach wykorzystałam materiał pomocniczy do europejskiej ramy referencyjnej „Profile deutsch”.

Wyniki badań przedstawione zostały w odniesieniu do czterech szczegółowych pytań badawczych:

- Jak z biegiem czasu żmienia sie nastawienie studentón do Europejskiego porffolio jesylkowego i samooceny?

Dla większości studentów dokument Rady Europy - EPJ był wcześniej nieznany. Nastawienie wielu studentów było zatem początkowo dosyć sceptyczne. Pytali np.:

Po co to wsyystko?

EPJ zdaje sie być driecinna idea.

Można przecież uykoraystać ten czas sensowniej.

\footnotetext{
${ }^{56}$ Badanie w działaniu zakłada wywołanie przez badacza zmian w wybranej rzeczywistości z zamiarem doskonalenia własnej pracy i jednoczesne badanie tych zmian (Zawadzka 2004). Bardziej szczegółowe wskazówki dotyczące badania action research można znaleźć m.in. w pracach Palki (1998), Łobockiego (1999), Cohen i Manion (1994), Nuan (1992).
} 
Diagram nr 1 przedstawia wstępną opinię studentów: Jak ocenia Pan/i idę Europejskiego portfolio jezykowego?

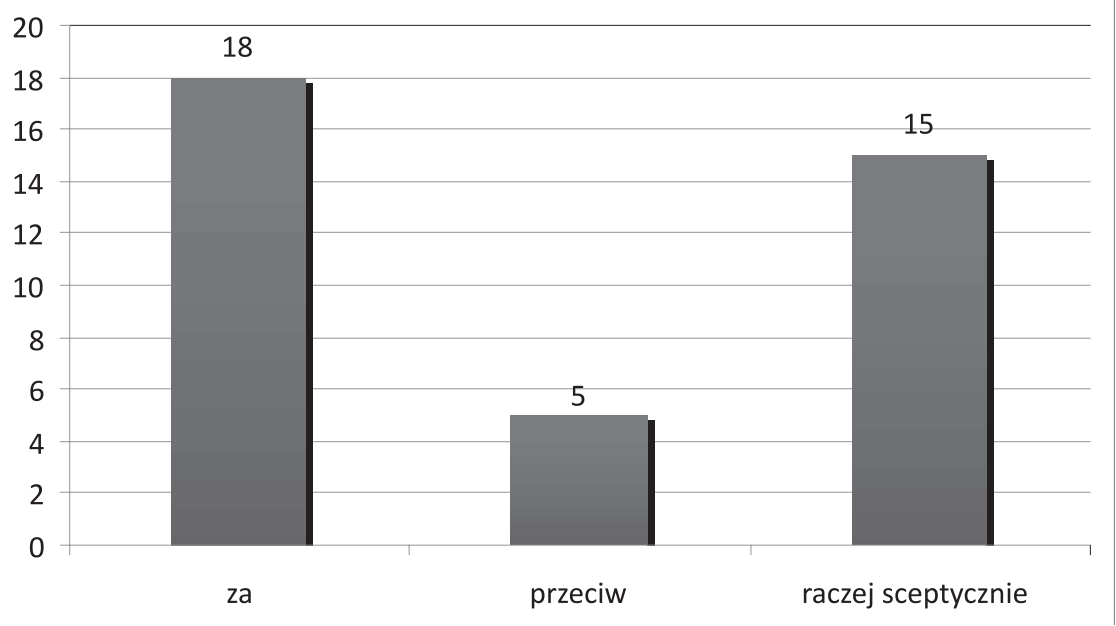

Diagram1: Jak ocenia Pan/i ideę Europejskiego portflio językowego?

Mimo, iż samoocena wymaga osobistego zaangażowania i aktywności uczących się, studenci przyjęli ją chętnie, choć początkowo z pewną dozą nieufności, traktując ja jako konieczność. Z biegiem czasu nastawienie studentów uległo zmianie. Badani przyzwyczaili się do pracy z EPJ, twierdzili nawet, iż sprawia im ona przyjemność. Po każdej pracy pisemnej studenci dokonywali pisemnej samooceny, również po każdym semestrze oceniali poziom biegłości językowej w zakresie sprawności pisania. Badani studenci byli otwarci, starali się być elastyczni i nie brakowało im krytycznego spojrzenia na siebie. Dzięki prowadzonej na bieżąco obserwacji i licznym dyskusjom czy wywiadom, mogę stwierdzić, że postawa studentów wobec samooceny uległa zmianie. Z czasem nawet osoby nieśmiałe przekonały się do nieznanych im wcześniej technik ewaluacji i chętnie je stosowali, doceniając ich przydatność w rozwijaniu sprawności pisania. Nieliczni z badanej grupy unikali samooceny. Z mojej obserwacji wynika jednak, że były to osoby mało zmotywowane do nauki w ogóle, które po pierwszym semestrze studiów, nie kontynuowały nauki w naszej uczelni.

Drugie szczegółowe pytanie badawcze:

- Jak wplywa Europejskie portfolio jezylkowe i kontrola prac pisemnych na rozwój sprawności pisania?

Początkowo studenci zwracali uwage przede wszystkim na poprawność gramatyczną wypowiedzi pisemnej, ubogie słownictwo, ale także systematyczna pracę. 
Diagram nr 2 przedstawia zagadnienia z badania pilotażowego, z którymi studenci mają największy problem.

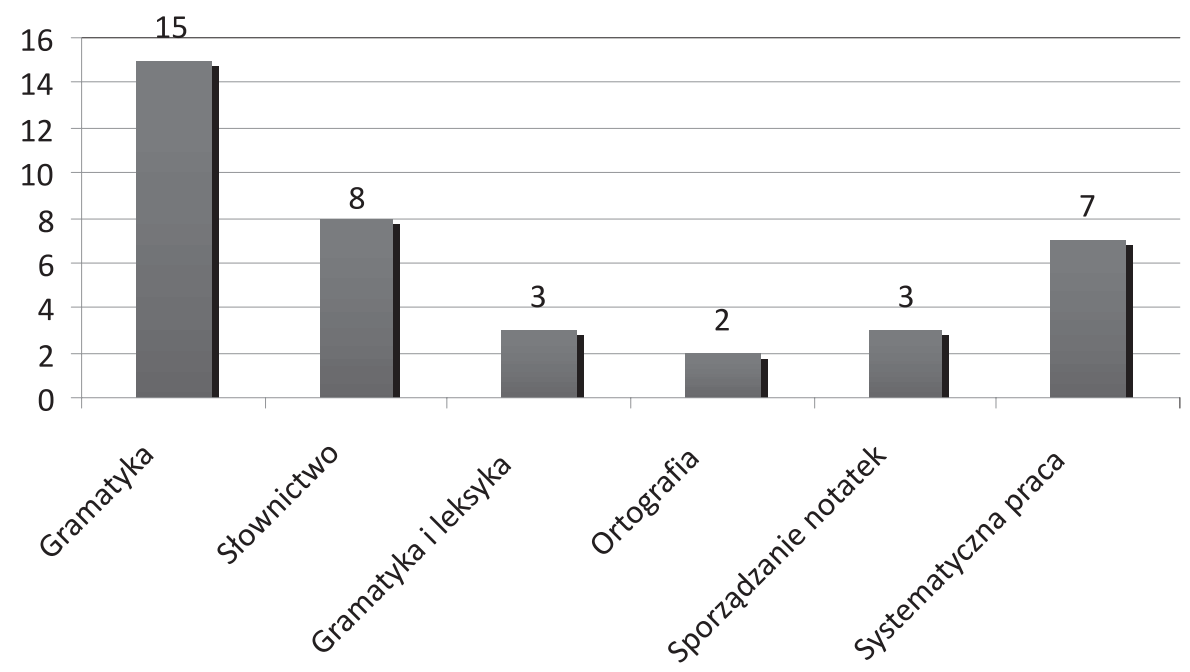

Diagram 2: Co sprawia Pani/Panu największy problem podczas nauki języka niemieckiego?

We wstępnej fazie zestaw kryteriów wymienionych przez studentów był dość ubogi, z czasem, po licznych dyskusjach wyłonili oni potrzebne kryteria dotychczas nieobecne w ich repertuarze. Następne autoewaluacje skupiały się przede wszystkim na formie wypowiedzi pisemnej, kompozycji tekstu, komunikatywności, treści, w dalszej kolejności bogactwie leksykalnym, poprawności gramatycznej i stylu wypowiedzi. Dokonując końcowej samooceny i autoewaluacji studenci posługiwali się wyżej wymienionymi kryteriami, umieli ocenić napisany przez siebie tekst w sposób bardziej obiektywny. Podczas prowadzonych badań studenci uznali za bardzo przydatną umiejętność dostrzegania własnych błędów i wyrazili chęć rozwijania samooceny. Po zakończeniu zadania towarzyszyła im zwykle refleksja, że nie wykorzystali w pełni swoich możliwości językowych, a język, jakim się posługiwali był zbyt prosty.

Wprowadzenie samooceny miało więc służyć rozwijaniu przez studentów autokontroli i autokorekty. Dzięki niej uczyli się dostrzegać własne błędy i ich unikać. Udało mi się również zaobserwować doświadczenie przez studentów własnej skuteczności, uwrażliwienie na sterowanie własnym procesem uczenia się oraz rozwój samoświadomości w tym procesie.

Kolejny diagram (nr 3) uświadamia, jak zmieniło się podejście studentów do badanego problemu i przedstawia samoocenę badanych: Czy stał/a się Pan/i bardziej samodzielna w nauce języka niemieckiego? 


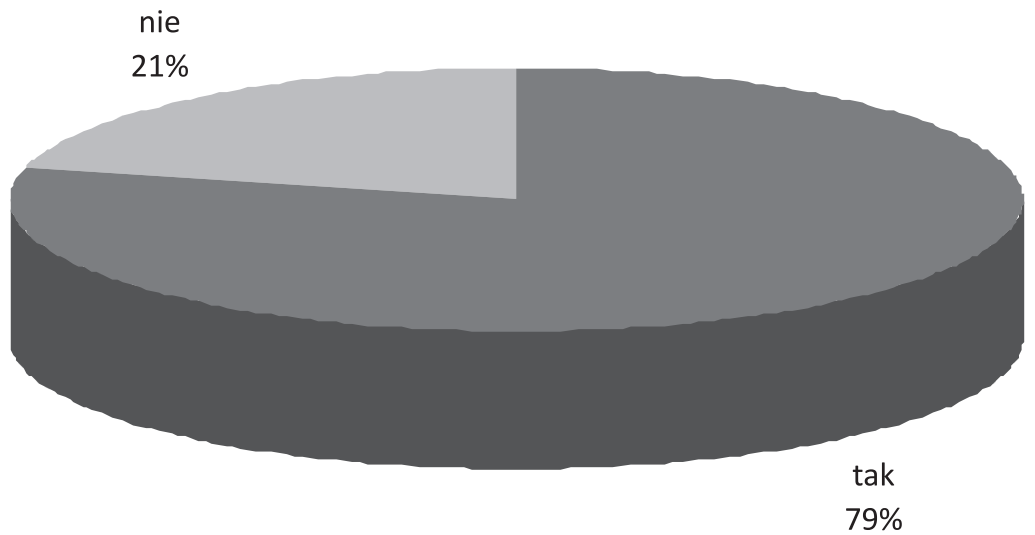

Diagram 3: Czy stała się Pani/stał się Pan bardziej samodzielny podczas nauki języka obcego?

Przedstawione w diagramie wyniki ankiety podkreślają pozytywne zmiany nastawienia badanych do samooceny. Zmiany te łączyć można z osobowościa studentów. Im bardziej otwarci, krytyczni i elastyczni byli studenci, tym chętniej podejmowali nowe wyzwania i akceptowali pracę z nowym dokumentem.

Trzecie szczegółowe pytanie badawcze:

- $\quad C_{z y}$ Europejskie portfolio jezykoowe jest nieodzown a czésciq samooceny?

Europejskie portfolio językowe z pewnością wspiera rozwój autonomii uczących się oraz rozwój umiejętności autokorekty. Europejskie portfolio językowe jest jednocześnie przykładem, jak można motywować i zachęcać uczących się do podejmowania samooceny. Mówiąc o samoocenie należało w pierwszej kolejności zachęcić badanych do refleksji nad ocenianiem w ogóle. Prezentowany diagram (nr 4) Czy zdaniem Pani/Pana można oddzielić ocenianie od oceny? - wskazuje jednak na obawy studentów, czy ocenę można oddzielić od oceniania? 


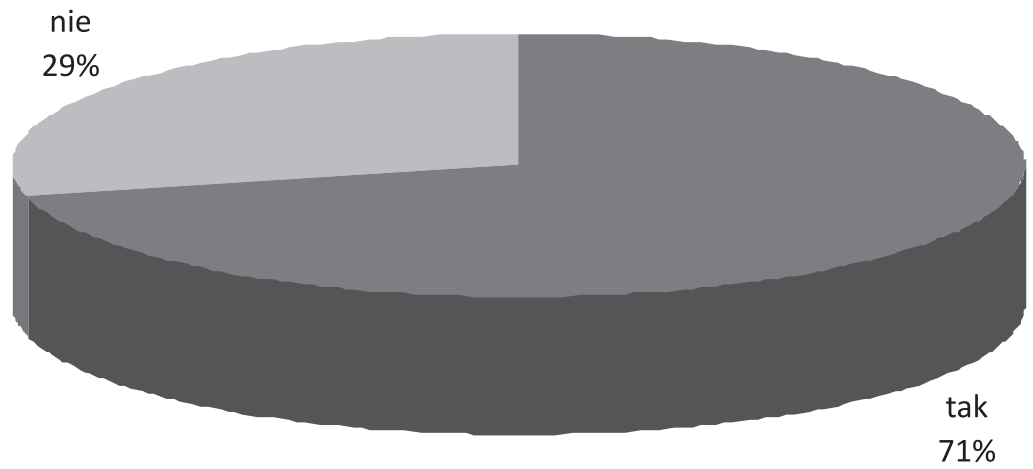

Diagram 4: Czy zdaniem Pani/Pana można oddzielić ocenianie od oceny?

Zdania w tej kwestii były podzielone. Aby pokazać studentom, jak trudno dokonać trafnej oceny, zachęcałam badanych do analizowania własnych słabych i mocnych stron, partnerskiej oceny, jak i samooceny z wykorzystaniem EPJ. Prezentowany instrument jest zatem przykładem efektywnej samooceny. $\mathrm{O}$ autoewaluacji można jednak mówić w szerszym zakresie. Portfolio jest bowiem jednym z wielu instrumentów autoewaluacyjnych, dzięki któremu uczący się osiągają sukces. Diagram nr 5 pokazuie wvniki odbowiedzi na pvtanie: czv widzi Pan/i zaletv EPI?

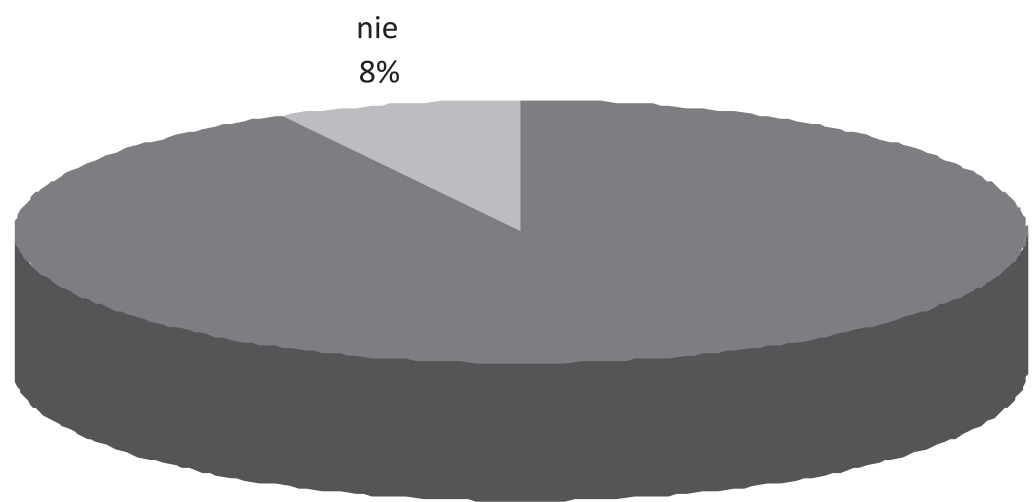

tak

$92 \%$

Diagram 5: Czy widzi Pan/i zalety EPJ? 
Można zatem wnioskować, że badani byli/są zadowoleni z osiagniętych rezultatów, odnotowali postęp w rozwijaniu własnej kompetencji w zakresie sprawności pisania i stali się bardziej samodzielni. Uzupełniając regularnie własne teczki z pracami (w ramach Dossier) oraz dokonując systematycznej refleksji poprzez dodawany komentarz, studenci przyczyniali się do rozwoju własnej autonomii, co mogli również odnotować w Biografii językowej.

Czwarte szczegółowe pytanie badawcze:

- Cay Europejskie portfolio jesylkowe jest efektywnym sposobem samooceny w rozwijanin sprawności pisania?

Można stwierdzić, że EPJ jest efektywnym instrumentem autonomizacyjnym. Uczący się potrafią ocenić siebie oraz własne teksty. Są zmotywowani do planowania procesu uczenia się. W przyszłości badani studenci wyrażają chęć pracy z Europejskim portfolio językowym nie tylko w ramach nauki języka niemieckiego, co przedstawia diagram nr 6: Czv bedzie Pan/i w przvszłości korzvstać z EPI?

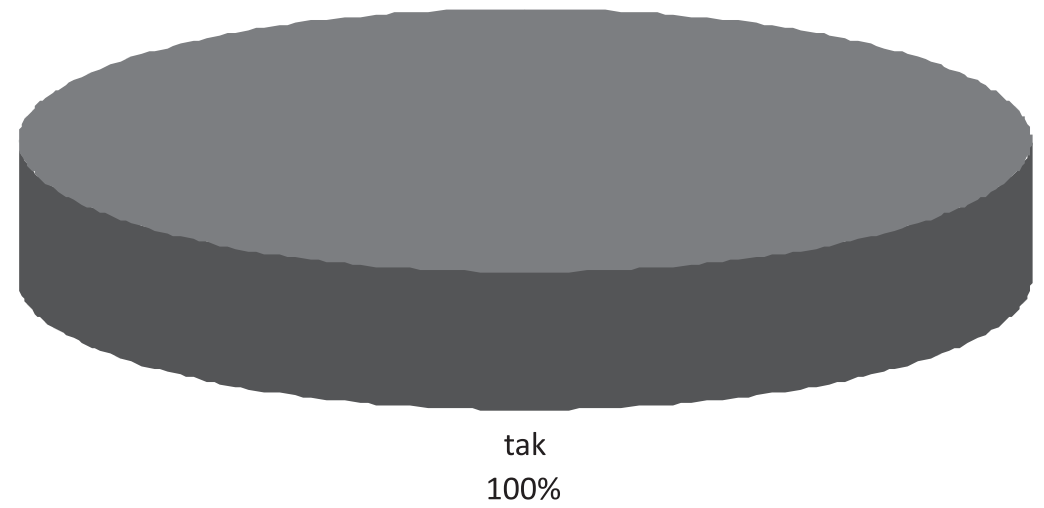

Diagram 6: Czy będzie Pan/i w przyszłości korzystać z EPJ?

Prezentowany diagram ilustruje deklaracje badanych, którzy w 100\% wyrażają chęć dalszej pracy z EPJ. Po zakończonych badaniach, a tym samym ćwiczeniach $z$ redagowania tekstów część badanych zaniechała jednakże pracy z tym instrumentem. Optymistycznym pozostaje jednak fakt, że ponad 50\% kontynuowała pracę $\mathrm{z}$ portfolio. W tym miejscu nasuwa się refleksja, jak wspierać mechanizmy rozwijania świadomości uczących się poza ławą szkolną, poza sformalizowaną instytucją oraz jak wspierać uczenie się przez całe życie. 


\section{Wnioski}

Reasumując można stwierdzić, iż EPJ wspiera autokorektę, samoocenę, a zatem autoewaluację studentów i przyczynia się do autonomii uczących się.

Wyniki powyższego studium potwierdzaja przydatność samooceny jako techniki rozwijającej świadomość i autorefleksję uczących się. Samoocena umożliwia świadomą i zorganizowaną przebudowę osobistej koncepcji uczenia się języka, która opiera się na analizie aktualnego stanu kompetencji, a portfolio językowe jako instrument samooceny jest więc również przydatne na poziomie zaawansowanym, gdzie stopień opanowania języka pozwala na większą samodzielność i swobodę $\mathrm{w}$ indywidualnym doborze sposobów uczenia się (Aleksandrzak 2002).

Europejskie portfolio językowe jest ciekawym narzędziem pedagogicznym i interesującym instrumentem autoewaluacji i samooceny, którego zastosowanie w praktyce umożliwia zwiększenie efektywności nauczania języków obcych, w przypadku przeprowadzonych i przedstawionych tutaj badań pozwala rozwinąć autorefleksję i samokontrolę w zakresie rozwijania sprawności pisania oraz wspiera autonomię uczących się. Dossier, w którym znajdują się prace studentów jest tworzone samodzielnie i tym samym dają świadectwo przebiegu procesu uczenia się języka obcego.

Przygotowanie i samodzielne prowadzenie teczki daje możliwość uczącemu się aktywnego i świadomego udziału w procesie uczenia się języków obcych. Dzięki temu można tym procesem lepiej kierować i dokonywać oceny tego, co już się udało osiagnąć, a także zaplanować dalszy tok kształcenia.

Należy jednak pamiętać, że sama świadomość istnienia Europejskiego portfolio językowego jak i instrumentów samooceny nie wystarczy, by świadomie dokonywać refleksji dotyczącej procesu nauki języka obcego. Tylko systematyczne korzystanie z technik samooceny daje możliwość rozwoju autonomii uczących się.

Mając na uwadze złożoność problemu rozwijania sprawności pisania jak i autonomii uczących się oraz ich autoewaluacji, sądzę, iż warto w przyszłości zająć się badaniem wspierania samodzielnej nauki poza klasą szkolną. Potrzebna jest również otwarta dyskusja na temat szczegółowego opisu kompetencji w ramach rozwijania sprawności pisania. Byłoby wskazane także podjąć próbę odpowiedzi na pytanie, w jakim stopniu uczący się jest w stanie samodzielnie rozwijać własną kompetencję pisania i przy użyciu jakich tekstów czy metod.

Zgłębianie wyżej wymienionych zagadnień sprawia, iż pojawia się coraz więcej znaków zapytania. Zwiększa się liczba pytań czekających na odpowiedź. W chwili obecnej istotne jest jednak rozprzestrzenianie idei pracy z Europejskim portfolio językowym, wspieranie autonomii uczenia się oraz dokonywanie autorefleksji. 


\section{BIBLIOGRAFIA}

Aleksandrzak, M. 2002. „Rozwijanie umiejętności samooceny” [w] Autonomizacja w dydaktyce jezylków obcych (red. Wilczyńska, W.) Poznań: Wydawnictwo Naukowe UAM.

Bimmel, P./ Rampillon, U. 2000. Lernerautonomie und Lernstrategien. Berlin München Wien: Langenscheidt.

Cohen, L., Manion, L. 1994. Research Methods in Education - $4^{\text {th }}$. London and New York: Routledge.

Council of Europe. 2003. Europejski system opisu kształcenia jesylkowego: uczenie sie, nauczanie, ocenianie. Warszawa: Wydawnictwa Centralnego Ośrodka Doskonalenia Nauczycieli.

Europejskie porffolio jesykowe. 2004. Warszawa: Wydawnictwa Centralnego Ośrodka Doskonalenia Nauczycieli.

Łobocki, M. 1999. Wprowadzenie do metodologii badań pedagogicznych. Kraków: Oficyna Wydawnicza „Impuls”.

Nuan, D. 1992. Research Methods in Language Learning. Cambridge: CUP.

Palka, S. (red.)1998. Orientacje w metodologii badań pedagogicznych. Kraków: Wydawnictwo Uniwersytetu Jagiellońskiego.

Pfeiffer, W. 2001. Nauka jesykoón obcych. Od praktyki do praktyki. Poznań: Wagros.

Profile deutsch. Gemeinsamer europäischer Referenarabmen. 2002. Berlin: Langenscheidt.

Zawadzka, E. 2004. Naucsyciele jesylkón obcych w dobie przemian. Kraków: Oficyna Wydawnicza „Impuls”.

Zuchewicz, T. 2002. „O pisaniu w języku obcym, Internecie oraz autonomii studentów filologii germańskiej" [w] Wokót autonomizacii w dydaktyce jezylków obcych (red. Wilczyńska, W.) Poznań: Wydawnictwo Naukowe UAM. 